\title{
HUBUNGAN KESEIMBANGAN ASUPAN GIZI DAN AKTIVITAS FISIK DENGAN KONDISI FISIK ANAK SD DI KECAMATAN KOTANOPAN
}

\author{
Dr. Erli Mutiara, M.Si, Dra. Adikahriani, M.Si dan Elvi Novi Yanti \\ erlimutiara@gmail.com
}

\begin{abstract}
ABSTRAK
Penelitian ini bertujuan untuk: (1) Menganalisis hubungan keseimbangan asupan gizi dengan kondisi fisik anak. (2) Menganalisis hubungan aktivitas fisik dengan kondisi fisik anak. (3) Menganalisis hubungan keseimbangan asupan gizi dan aktivitas fisik dengan kondisi fisik anak. Lokasi penelitian di SDN 190, SDN 193 dan SDN 200 Kecamatan Kotanopan. Pengambilan sampel dengan teknik random sampling. Jumlah sampel 70 siswa. Teknik pengumpulan data dengan wawancara menggunakan kuesioner. Data keseimbangan asupan gizi diperoleh dengan recall konsumsi 2x24 jam, data kondisi fisik diperoleh dari hasil penimbangan berat badan dan data aktivitas fisik diperoleh dengan recall aktivitas $2 \times 24$ jam. Analisis data menggunakan statistik deskriptif, uji Korelasi Pearson dan Regresi Linear Berganda.

Hasil penelitian menunjukkan bahwa. Keseimbangan asupan gizi responden keseluruhannya termasuk kategori kurang. Kondisi fisik responden sebagian besar termasuk kategori normal/baik. Aktivitas fisik sebagian besar termasuk kategori aktivitas ringan. Hasil analisis korelasi Pearson menunjukkan bahwa keseimbangan asupan energi, karbohidrat, vitamin $A$, vitamin $C$, fosfor dan besi berhubungan positif nyata $(\mathrm{p}<0.05)$ dengan kondisi fisik, sedangkan kalsium berhubungan positif sangat nyata $(\mathrm{p}<0.01)$ dengan kondisi fisik. Hal ini menunjukkan bahwa semakin baik asupan zat gizi maka kondisi fisik anak juga akan semakin baik. Hasil uji statistik korelasi Pearson menunjukkan bahwa aktivitas fisik $(\mathrm{r}=$ $0.406 ; \mathrm{p}=0.000$ ) berhubungan negatif sangat nyata dengan kondisi fisik. Hal ini menunjukkan bahwa peningkatan aktivitas fisik akan diikuti penurunan kondisi fisik. Hasil analisis regresi linier berganda menunjukkan bahwa nilai $\mathrm{f}_{\text {hitung }}=2.521>\mathrm{f}_{\text {tabel }}=2.00$ atau $\mathrm{p}$ value $=0.013<\alpha=0.05$. Hal ini berarti keseimbangan asupan gizi dan aktivitas fisik secara simultan berhubungan signifikan dengan kondisi fisik anak.
\end{abstract}

\section{Kata kunci : Keseimbangan, asupan gizi, aktivitas fisik, kondisi fisik}

\section{Pendahuluan}

Asupan gizi pada anak sekolah dasar di beberapa wilayah di Indonesia sangat memprihatinkan, padahal asupan gizi yang baik setiap harinya dibutuhkan supaya mereka memiliki pertumbuhan, kesehatan dan kemampuan intelektual yang lebih baik sehingga menjadi generasi penerus bangsa yang unggul dan dapat mengharumkan nama bangsa di dunia Internasional. Hal ini sesuai dengan pendapat Almatsier (2001), yang mengatakan bahwa pada dasarnya asupan gizi yang diterima pada anak-anak sekolah dasar masih menunjukkan kurang menerima asupan gizi yang baik untuk perkembangan tubuh dan intelektualitas yang tinggi, oleh karena itu sudah selayaknya pemerintah, masyarakat terutama keluarga untuk dapat memberikan asupan gizi yang cukup untuk perkembangan dan pertumbuhan anak.

Anak sekolah merupakan generasi penerus bangsa dan modal pembangunan. Salah satu upaya penting yang dapat dilakukan untuk mempertinggi kualitas sumber daya anak sekolah dasar adalah dengan meningkatkan kualitas dan kuantitas makanan yang dikonsumsi sehari- 
Hubungan keseimbangan asupan gizi dan aktivitas fisik Dengan kondisi fisik anak sd di kecamatan kotanopan

hari, karena anak pada usia sekolah sedang dalam proses pertumbuhan dan perkembangan yang cepat yang ditandai oleh pertambahan berat badan (Hayati 2010). Karena itu, perhatian terhadap gizi anak sekolah bukanlah hal yang bisa ditawar-tawar lagi, karena gizi yang baik atau buruk yang dialami seorang anak sekolah merupakan pilihan dalam menentukan kesehatan dan kecerdasan anak.

Asupan zat gizi makanan pada seseorang dapat menentukan tercapainya tingkat kesehatan, atau sering disebut status gizi. Anak sekolah usia 6-12 tahun sangat memerlukan perhatian terutama dalam pemenuhan kebutuhan gizi (Handari dan Siti, 2005). Apabila konsumsi gizi makanan pada seseorang tidak seimbang dengan kebutuhan tubuh, maka akan terjadi malnutrisi (Notoatmodjo, 2003). Oleh karena itu, hal tersebut di atas benar-benar sangat membutuhkan perhatian dari orang tua dan tingkatkan ilmu pengetahuan orang tua. Orang tua harus mempunyai pengetahuan gizi karena gizi anak sangat ditentukan oleh orang tua sebagai pengasuh anak.

Kecamatan Kotanopan merupakan salah satu kecamatan di Kabupaten Mandailing Natal Provinsi Sumatera Utara. Di Kecamatan Kotanopan tersebut terdapat beberapa SD Negeri. Berdasarkan hasil pengamatan dan wawancara penulis pada Juni 2013 dengan beberapa orang siswa SD di Kotanopan, mereka sudah terbiasa setiap hari berangkat ke sekolah tanpa sarapan pagi dan di sekolah mereka membeli jajanan saat jam istirahat untuk memenuhi kebutuhan tubuhnya karena mereka sudah merasakan kelaparan. Sarapan pagi merupakan pasokan energi untuk otak yang paling baik agar dapat berkonsentrasi di sekolah. Kalaupun terburu-buru makan pagi, kemungkinan makanan itu tidak dapat memberikan kalori yang diperlukan selama anak berada di sekolah. Akibatnya, kebutuhan gizi anak tidak tercukupi, anak kekurangan tenaga untuk berpikir dan beraktivitas tidak dapat konsentrasi, cenderung malas, dan badan lemas. Menurut pendapat Khomsan (2010), sekarang banyak dijumpai anak yang jarang makan bersama keluarga dikarenakan orang tua yang terlalu sibuk dengan pekerjaannya masing-masing sehingga waktu makan bersama keluarga tidak rutin dilaksanakan. Karena apabila anak tidak makan bersama orang tua asupan gizi anak tidak akan terkontrol dengan baik, karena bisa saja anak tidak mengkonsumsi lauk pauk dan sayuran yang sudah diolah orang tua ataupun tidak ada makan sama sekali. Jika hal ini terus berlangsung maka dikhawatirkan anak sekolah tersebut akan mengalamai ketidakseimbangan asupan gizi.

Sementara jika dilihat kondisi fisik anak,sekitar 50 persen anak memiliki berat badan yang di bawah normal. Berbagai penelitian yang pernah dilakukan terhadap anak sekolah baik di kota maupun pedesaan di Indonesia, didapatkan kenyataan bahwa pada umumnya berat badan rata-rata anak sekolah dasar berada di bawah normal (Moehji, 2003).

Aktivitas fisik siswa tersebut umumnya mereka melakukan aktivitas berat seperti berlari, melompat dan melakukan gerakan-gerakan tubuh lainnya. Selain itu terdapat juga aktivitas anak yang selalu jalan kaki ketika berangkat ke sekolah karena jarak tempuh dari rumah ke sekolah masih bisa dilakukan dengan jalan kaki yaitu $\pm 500 \mathrm{~m}$ dan ada juga sekolah yang memiliki gedung bertingkat sehingga aktivitas anak lebih tinggi karena anak harus naik turun tangga untuk sampai ke kelasnya masing-masing. Di zaman sekarang, sebagian besar anak usia sekolah menggunakan waktunya sehari-hari untuk menonton televisi. Penelitian di Amerika pada anak-anak menunjukkan bahwa anak dengan lama waktu menonton televisi 5 jam per hari, memiliki resiko obesitas sebesar 5.3 kali lebih besar daripada anak 
dengan lama menonton 2 jam per hari (Hidayati, dkk, 2006). Karena, kebiasan anak menonton dalam waktu lama aktivitas anak pun akan semakin berkurang dan biasanya anak yang menonton dalam waktu yang lama dilengkapi dengan makanan cemilan. Hal tersebutlah yang mengakibatkan anak mengalami obesitas.

Aktivitas fisik akan berpengaruh terhadap kondisi fisik seseorang dan kondisi fisik dipengaruhi oleh asupan gizi. Asupan gizi yang seimbang akan menghasilkan anak-anak yang cerdas dan memiliki prestasi yang membanggakan.

Berdasarkan hal tersebut, maka perlu dilakukan penelitian dengan judul : "Hubungan Keseimbangan Asupan Gizi dan Aktivitas Fisik dengan Kondisi Fisik Anak di SD Kecamatan Kotanopan". Tujuan penelitian ini adalah mengidentifikasi karakteristik keluarga (pendidikan orang tua, pekerjaan orang tua, pendapatan orang tua dan besar keluarga) anak SD di Kecamatan Kotanopan. Menganalisis hubungan keseimbangan asupan gizi dengan kondisi fisik anak. Menganalisis hubungan aktivitas fisik dengan kondisi fisik anak. Menganalisis hubungan keseimbangan asupan gizi dan aktivitas fisik dengan kondisi fisik anak.

\section{Metode Penelitian}

Lokasi penelitian di SDN Kecamatan Kotanopan. Lokasi tersebut ditentukan secara purposive dengan kriteria berada di sekitar kota Kecamatan Kotanopan. Berdasarkan kriteria tersebut maka lokasi penelitian yaitu di SDN 190, SDN 193 dan SDN 200. Waktu penelitian ini bulan November 2013-Januari 2014. Populasi dalam penelitian ini adalah siswa kelas IV dan V SD karena siswa tersebut sudah dapat diwawancarai. Jumlah populasi dalam penelitian ini sebanyak 233 orang. Menurut Arikunto, (2010), jika jumlah subjeknya besar dapat diambil antara 10-15 atau 20-25\% atau lebih, tergantung dari kemampuan peneliti. Berdasarkan pendapat tersebut maka sampel diambil sebanyak 30 persen. Sehingga jumlah sampel sebanyak 70 anak, teknik pengambilan sampel secara random sampling.

Jenis data yang dikumpulkan meliputi data primer dan data sekunder. Data primer meliputi asupan gizi, kondisi fisik anak (berat badan) dan aktivitas fisik. Data asupan gizi dikumpulkan melalui wawancara dengan alat bantu kuesioner food recall $2 \times 24$ jam. Data kondisi fisik anak dikumpulkan dengan cara pengukuran berat badan dan umur anak. Berat badan diukur dengan menggunakan timbangan injak yang berkapasitas $150 \mathrm{~kg}$ dengan ketelitian $0,1 \mathrm{~kg}$. Sampel diukur pada posisi berdiri tegak tepat ditengah timbangan dan tanpa menggunakan alas kaki. Pembacaan angka dilakukan setelah angka petunjuk tidak bergerak. Data untuk aktivitas fisik dikumpulkan melalui wawancara langsung dengan alat bantu kuesioner aktivitas $2 \times$ 24 jam. Data yang diperoleh diolah dan dianalisis secara statistik deskriptif dengan menggunakan program SPSS versi 17,0 for windows. Data keseimbangan asupan gizi yang diperoleh dari kuesioner recall $2 \times 24$ jam kemudian dikonversikan ke dalam zat gizi dengan menggunakan aplikasi Nutrisurvey 2007. Masing-masing zat gizi dijumlahkan dan dihitung rata-rata konsumsi setiap hari dan hasilnya dibandingkan dengan zat gizi yang dianjurkan (AKG) dikali $100 \%$. Kemudian dikategorikan menjadi kategori kategori baik $(80-110 \%$ AKG) , kurang $(<80 \%$ $\mathrm{AKG}$ ), lebih (>110\% AKG) (WNPG, 2004). Menurut FAO/WHO/UNU (2001) besarnya aktivitas fisik yang dilakukan seseorang dalam 24 jam dinyatakan dalam Physical Activity Level (PAL) atau tingkat aktivitas fisik. PAL dapat ditentukan dengan rumus sebagai berikut:

$P A L=\frac{\sum(P A R \times \text { Alokasi Waktu Tiap Aktivitas })}{24 \text { jam }}$

Keterangan:

PAL = Physical Activity Level (tingkat aktivitas fisik) 
Hubungan keseimbangan asupan gizi dan aktivitas fisik Dengan kondisi fisik anak sd di kecamatan kotanopan

\section{$\mathrm{PAR}=$ Physical Activity Ratio (jumlah energi yang dikeluarkan untuk jenis aktivitas per satuan waktu tertentu)}

Aktivitas fisik kemudian dikategorikan menjadi tiga kategori, yaitu ringan $(1,40$ $1,69)$, sedang $(1,70-1,99)$, dan berat $(2,00-$ 2,40) (FAO/WHO/UNU, 2001). Data kondisi fisik yang merupakan penilaian status gizi dilakukan dengan menggunakan indeks antropometri berat badan menurut umur $(\mathrm{BB} / \mathrm{U})$ dengan cara menentukan Z-score. Hasil penilaian Z-score masing-masing di bandingkan dengan referensi WHO-NCHS. Untuk melihat hubungan keseimbangan asupan gizi dengan kondisi fisik dan aktivitas fisik dengan kondisi fisik dianalisis menggunakan uji Korelasi Pearson dan untuk melihat keeratan hubungan antara keseimbangan asupan gizi dan aktivitas dengan kondisi fisik anak dianalisis dengan menggunakan Regresi Linear Berganda.

\section{HASIL PENELITIAN DAN PEMBAHASAN}

\section{Usia Responden}

Berdasarkan hasil penelitian ini usia responden sebagian besar berumur 10 tahun sebanyak 65,71 persen dan berumur 11 tahun sebanyak 34,29 persen. Hasil penelitian ini sesuai dengan penelitian Utari (2009) yang mengatakan bahwa anak sekolah kelas IV dan V umumnya lebih banyak berusia 10 tahun dari pada 11 tahun. Sebaran responden berdasakan usia dapat dilihat pada Tabel 1.

Tabel 1.Sebaran Responden Berdasarkan

$$
\text { Usia }
$$

\begin{tabular}{|l|c|c|}
\hline Umur & n & \% \\
\hline 10 tahun & 46 & 65,71 \\
\hline 11 tahun & 24 & 34,29 \\
\hline Total & 70 & 100 \\
\hline
\end{tabular}

\section{Jenis Kelamin Responden}

Jumlah responden dalam penelitian ini sebanyak 70 orang dengan persentasi terbesar berjenis kelamin perempuan (Tabel
7). Hal ini sesuai dengan penelitian Utari (2009) yang mengatakan bahwa anak sekolah kelas IV dan V lebih banyak yang berjenis kelamin perempuan dari pada lakilaki.

Tabel 2. Sebaran Responden berdasarkan Jenis Kelamin

\begin{tabular}{|l|c|c|}
\hline \multicolumn{1}{|c|}{ Jenis Kelamin } & n & \% \\
\hline Laki-laki & 25 & 35,71 \\
\hline Perempuan & 45 & 64,29 \\
\hline Total & 70 & 100 \\
\hline
\end{tabular}

\section{Keseimbangan Asupan Gizi}

Keseimbangan asupan gizi merupakan keseimbangan asupan gizi dengan kebutuhan tubuh (BKP, 2004). Berdasarkan hasil penelitian pada Tabel 3 dapat dilihat asupan zat gizi responden pada zat gizi makro yaitu energy, karbohidrat, lemak dan protein berada pada kategori kurang. Baik pada jenis kelamin laki-laki maupun pada jenis kelamin perempuan. Bila dibandingkan dengan angka kecukupan zat gizi yang direkomendasikan oleh Widya Karya Nasional Pangan dan Gizi (2012) yakni energi sebanyak $2100 \mathrm{kkal} / \mathrm{kap} / \mathrm{hari}$ pada jenis kelamin laki-laki dan 2000 $\mathrm{kkal} / \mathrm{kap} / \mathrm{hari}$ pada jenis kelamin perempuan, karbohidrat sebanyak $289 \mathrm{~g} / \mathrm{kap} / \mathrm{hari}$ pada jenis kelamin laki-laki dan $275 \mathrm{~g} / \mathrm{kap} / \mathrm{hari}$ pada jenis kelamin, lemak sebanyak 70 $\mathrm{g} / \mathrm{kap} / \mathrm{hari}$ pada jenis kelamin laki-laki dan $67 \mathrm{~g} / \mathrm{kap} / \mathrm{hari}$ pada jenis kelamin perempuan, dan protein sebanyak $56 \mathrm{~g} / \mathrm{kap} / \mathrm{hari}$ pada jenis kelamin laki-laki dan $60 \mathrm{~g} / \mathrm{kap} / \mathrm{hari}$ pada jenis kelamin perempuan, maka rataan asupan zat gizi makro di bawah rataan tingkat kecukupan yang dianjurkan. Hal ini disebabkan karena kurangnya konsumsi makanan anak sekolah setiap harinya, baik yang diperoleh dari makanan jajanan saat disekolah maupun di rumah. Kurangnya zat gizi makro ditandai dengan badan lemah, tidak bersemangat, tidak bisa konsentrasi dan badannya kurus karena asupan zat gizi makro dari makanan tidak mencukupi. Sedangkan zat gizi makro yang ada dalam tubuh telah dipergunakan untuk berpikir dan beraktivitas bahkan persediaan lemak dalam tubuh pun 
Hubungan keseimbangan asupan gizi dan aktivitas fisik Dengan kondisi fisik anak sd di kecamatan kotanopan

akhirnya terkuras juga. Hal ini sesuai dengan pendapat Devi (2012), apabila anak sekolah mengalami kekurangan protein maka akan terhambatnya pertumbuhan fisik karena pada usia anak terutama pertumbuhan tinggi badan sangat pesat dan untuk itu diperlukan protein, terhambatnya perkembangan otak karena otak membutuhkan protein untuk membangun dan menjaga sel-sel otak, dan menurunnya daya tahan tubuh anak terhadap penyakit karena protein dibutuhkan untuk antibodi atau zat imun.

Tabel 3. Sebaran Responden Berdasarkan Keseimbangan Asupan Gizi

\begin{tabular}{|c|c|c|c|c|c|c|}
\hline \multirow{2}{*}{$\begin{array}{c}\text { Keseimbangan Asupan } \\
\text { Gizi }\end{array}$} & \multicolumn{2}{|c|}{ Laki-Laki } & \multicolumn{2}{|c|}{ Perempuan } & \multicolumn{2}{|c|}{ Total } \\
\hline & $\mathbf{n}$ & $\%$ & n & $\%$ & $\mathbf{n}$ & $\%$ \\
\hline \multicolumn{7}{|l|}{ Energi (Kkal) } \\
\hline Kurang & 25 & 100 & 45 & 100 & 70 & 100 \\
\hline Baik & 0 & 0 & 0 & 0 & 0 & 0 \\
\hline Lebih & 0 & 0 & 0 & 0 & 0 & 0 \\
\hline Total & 25 & 100 & 45 & 100 & 70 & 100 \\
\hline Rataan \pm SD & \multicolumn{2}{|c|}{$969.58 \pm 219.97$} & \multicolumn{2}{|c|}{$933.33 \pm 291.33$} & \multicolumn{2}{|c|}{$946.28 \pm 266.95$} \\
\hline Min-max & \multicolumn{2}{|c|}{$576.0-1573.5$} & \multicolumn{2}{|c|}{$428.8-1559.3$} & \multicolumn{2}{|c|}{$428.8-1573.5$} \\
\hline \multicolumn{7}{|l|}{ Karbohidrat (g) } \\
\hline Kurang & 25 & 100 & 44 & 97.8 & 69 & 98.57 \\
\hline Baik & 0 & 0 & 1 & 2.2 & 1 & 1.43 \\
\hline Lebih & 0 & 0 & 0 & 0 & 0 & 0 \\
\hline Total & 25 & 100 & 45 & 100 & 70 & 100 \\
\hline Rataan \pm SD & \multicolumn{2}{|c|}{$122.716 \pm 28.64$} & \multicolumn{2}{|c|}{$128.19 \pm 42.35$} & \multicolumn{2}{|c|}{$126.24 \pm 37.90$} \\
\hline Min-max & \multicolumn{2}{|c|}{ 79.4-181.2 } & \multicolumn{2}{|c|}{$64.1-223.2$} & \multicolumn{2}{|c|}{$64.1-223.2$} \\
\hline \multicolumn{7}{|l|}{ Lemak (g) } \\
\hline Kurang & 22 & 88.0 & 43 & 95.6 & 65 & 92.9 \\
\hline Baik & 3 & 12.0 & 2 & 4.4 & 5 & 7.1 \\
\hline Lebih & 0 & 0 & 0 & 0 & 0 & 0 \\
\hline Total & 25 & 100 & 45 & 100 & 70 & 100 \\
\hline Rataan \pm SD & \multicolumn{2}{|c|}{$37.67 \pm 12.29$} & \multicolumn{2}{|c|}{$32.06 \pm 12.94$} & \multicolumn{2}{|c|}{$34.06 \pm 12.91$} \\
\hline Min-max & & 5.3 & & & & \\
\hline Protein $(\mathrm{g})$ & & & & & & \\
\hline Kurang & 18 & 72.0 & 39 & 86.7 & 57 & 81.4 \\
\hline Baik & 6 & 24.0 & 5 & 11.1 & 11 & 15.7 \\
\hline Lebih & 1 & 4.0 & 1 & 2.2 & 2 & 2.9 \\
\hline Total & 25 & 100 & 45 & 100 & 70 & 100 \\
\hline Rataan \pm SD & & 12.42 & & 2.04 & & \\
\hline Min-max & & 88.7 & & 9.1 & & \\
\hline Vitamin A $(\mu \mathrm{g})$ & & & & & & \\
\hline Kurang & 25 & 100 & 42 & 93.3 & 67 & 95.7 \\
\hline Baik & 0 & 0 & 2 & 4.4 & 2 & 2.9 \\
\hline Lebih & 0 & 0 & 1 & 2.2 & 1 & 1.4 \\
\hline Total & 25 & 100 & 45 & 100 & 70 & 100 \\
\hline Rataan \pm SD & & 84.77 & 195 & 64.97 & & 1.83 \\
\hline Min-max & & 34.5 & & 21.9 & & \\
\hline Vitamin C (mg) & & & & & & \\
\hline Kurang & 18 & 72.0 & 32 & 71.1 & 49 & 71.4 \\
\hline Baik & 6 & 24.0 & 8 & 17.8 & 15 & 20.0 \\
\hline Lebih & 1 & 4.0 & 5 & 11.1 & 6 & 8.6 \\
\hline Total & 25 & 100 & 45 & 100 & 70 & 100 \\
\hline Rataan \pm SD & & 19.98 & & 8.42 & & \\
\hline Min-max & & 0.1 & & & & \\
\hline Kalsium (mg) & & & & & & \\
\hline Kurang & 25 & 100 & 45 & 100 & 70 & 100 \\
\hline Baik & 0 & 0 & 0 & 0 & 0 & 0 \\
\hline
\end{tabular}

Dr. Erli Mutiara, M.Si, Dra. Adikahriani, M.Si dan Elvi Novi Yanti. Dosen Jurusan 
Hubungan keseimbangan asupan gizi dan aktivitas fisik Dengan kondisi fisik anak sd di kecamatan kotanopan

\begin{tabular}{|c|c|c|c|c|c|c|}
\hline \multirow{2}{*}{$\begin{array}{c}\text { Keseimbangan Asupan } \\
\text { Gizi }\end{array}$} & \multicolumn{2}{|c|}{ Laki-Laki } & \multicolumn{2}{|c|}{ Perempuan } & \multicolumn{2}{|c|}{ Total } \\
\hline & $\mathbf{n}$ & $\%$ & $\mathbf{n}$ & $\%$ & $\mathbf{n}$ & $\%$ \\
\hline Lebih & 0 & 0 & 0 & 0 & 0 & 0 \\
\hline Total & 25 & 100 & 45 & 100 & 70 & 100 \\
\hline Rataan \pm SD & \multicolumn{2}{|c|}{$161.89 \pm 113.27$} & \multicolumn{2}{|c|}{$205.52 \pm 188.97$} & \multicolumn{2}{|c|}{$189.94 \pm 166.36$} \\
\hline Min-max & \multicolumn{2}{|c|}{$73.3-546-6$} & \multicolumn{2}{|c|}{$30.9-811.9$} & \multicolumn{2}{|c|}{$30.9-811.9$} \\
\hline \multicolumn{7}{|l|}{ Fosfor (mg) } \\
\hline Kurang & 25 & 100 & 44 & 97.8 & 69 & 98.6 \\
\hline Baik & 0 & 0 & 1 & 2.2 & 1 & 1.4 \\
\hline Lebih & 0 & 0 & 0 & 0 & 0 & 0 \\
\hline Total & 25 & 100 & 45 & 100 & 70 & 100 \\
\hline Rataan \pm SD & \multicolumn{2}{|c|}{$511.85 \pm 167.26$} & \multicolumn{2}{|c|}{$522.89 \pm 196.36$} & \multicolumn{2}{|c|}{$518.95 \pm 185.33$} \\
\hline Min-max & \multicolumn{2}{|c|}{$294.3-919.7$} & \multicolumn{2}{|c|}{$206.4-1041.4$} & \multicolumn{2}{|c|}{$206.4-1041.4$} \\
\hline \multicolumn{7}{|l|}{ Besi (mg) } \\
\hline Kurang & 25 & 100 & 45 & 100 & 70 & 100 \\
\hline Baik & 0 & 0 & 0 & 0 & 0 & 0 \\
\hline Lebih & 0 & 0 & 0 & 0 & 0 & 0 \\
\hline Total & 25 & 100 & 45 & 100 & 70 & 100 \\
\hline Rataan \pm SD & \multicolumn{2}{|c|}{$4.17 \pm 0.98$} & \multicolumn{2}{|c|}{$4.04 \pm 1.79$} & \multicolumn{2}{|c|}{$4.08 \pm 1.55$} \\
\hline Min-max & \multicolumn{2}{|c|}{$2.5-6.1$} & \multicolumn{2}{|c|}{$1.6-9.3$} & \multicolumn{2}{|c|}{$1.6-9.3$} \\
\hline
\end{tabular}

Bila dilihat konsumsi zat gizi mikro yaitu vitamin A, C, kalsium, fosfor dan zat besi (Tabel 3) juga dibawah standar yang direkomendasikan oleh Widya Karya Nasional Pangan dan Gizi (2012) baik pada jenis kelamin laki-laki dan perempuan yaitu vitamin A sebanyak $600 \mu \mathrm{g} / \mathrm{kap} / \mathrm{hari}$, vitamin C sebanyak $50 \mathrm{mg} / \mathrm{kap} / \mathrm{hari}$, kalsium sebanyak $1200 \mathrm{mg} / \mathrm{kap} /$ hari fosfor sebanyak $1250 \mathrm{mg} / \mathrm{kap} / \mathrm{hari}$ dan besi sebanyak 13 mg/kap. Hal ini disebabkan karena kurangnya asupan vitamin A yang diperoleh dari makanan sehari-hari. Kekurangan vitamin A dapat menyebabkan gangguan mata seperti rabun senja, bila berlanjut dapat menyebabkan penurunan fungsi kornea dan menyebabkan kematian. Selain itu, dapat menyebabkan terganggunya perkembangan otak karena vitamin A membantu membangun protein otak (Devi, 2012). Menurut Devi (2012) anak sekolah saat ini menghadapi masalah gizi ganda, yaitu di satu sisi gizi kurang yang berakibat pada tidak optimalnya pertumbuhan fisik dan kecerdasan. Namun di sisi lain menghadapi gizi lebih yang mengancam kesehatan anak nantinya seperti timbulnya penyakit degeneratif, yaitu obesitas, hipertensi, diabetes, stroke dan lain-lain. Tetapi, dalam penelitian ini masalah gizi yang di alami anak adalah masalah gizi kurang. Masalah gizi kurang dapat terjadi karena kekurangan zat gizi makro seperti energi, protein, lemak dan dapat pula terjadi karena kekurangan zat gizi mikro seperti vitamin $\mathrm{A}$, besi dan seng. Hal ini disebabkan kurangnya asupan sumber zat gizi yang dibutuhkan anak. Anak tidak mengonsumsi gizi seimbang, tidak sarapan pagi, dan jajanan yang tidak sehat.

\section{Aktivitas Fisik}

Aktivitas fisik dikategorikan menjadi 3 kategori yaitu, ringan, sedang dan berat. Besarnya aktivitas yang dilakukan seseorang selama 24 jam dinyatakan dalam Physical Activity Level (PAL). Berdasarkan hasil penelitian sebaran reponden berdasarkan aktivitas fisik yang disajikan pada Tabel 4 , pada jenis kelamin laki-laki sebanyak 56.0 persen melakukan aktivitas sedang dan 44.0 persen melakukan aktivitas ringan. Pada jenis kelamin perempuan sebanyak 57.8 melakukan aktivitas ringan, sebanyak 35.6 persen melakukan aktivitas sedang dan sebanyak 6.7 persen melakukan aktivitas berat. Aktivitas seluruh responden berdasarkan perhitungan PAL berkisar antara 1.40 hingga 2.22 dengan rataan $1.68 \pm 0.19$. Hal ini disebabkan karena anak sekolah lebih banyak melakukan aktivitas 
Hubungan keseimbangan asupan gizi dan aktivitas fisik Dengan kondisi fisik anak sd di kecamatan kotanopan

yang ringan baik di sekolah maupun di luar sekolah. Hasil penelitian ini sejalan dengan hasil Riskesdas (2007), bahwa sebagian besar anak usia sekolah melakukan aktivitas fisik pada kategori ringan. Artinya bagi anak usia sekolah yang memiliki aktivitas aktif dan sangat aktif akan membutuhkan energi lebih banyak lagi.

Tabel 4. Sebaran Responden Berdasarkan Aktivitas anak

\begin{tabular}{|l|c|c|c|c|c|c|}
\hline \multirow{2}{*}{ Aktivitas anak } & \multicolumn{2}{|c|}{ Laki-Laki } & \multicolumn{2}{c|}{ Perempuan } & \multicolumn{2}{c|}{ Total } \\
\cline { 2 - 7 } & $\mathbf{n}$ & $\mathbf{\%}$ & $\mathbf{n}$ & $\mathbf{\%}$ & $\mathbf{n}$ & \% \\
\hline Ringan & 11 & 44.0 & 26 & 57.8 & 37 & 52.86 \\
\hline Sedang & 14 & 56.0 & 16 & 35.6 & 30 & 42.86 \\
\hline Berat & 0 & 0 & 3 & 6.7 & 3 & 4.29 \\
\hline Total & 25 & 100 & 45 & 100 & 70 & 100 \\
\hline Rataan \pm SD & \multicolumn{2}{|c|}{$1.71 \pm 0.17$} & \multicolumn{2}{c|}{$1.67 \pm 0.19$} & \multicolumn{2}{c|}{$1.68 \pm 0.19$} \\
\hline Min-max & \multicolumn{2}{|c|}{$1.43-1.99$} & \multicolumn{2}{c|}{$1.40-2.22$} & \multicolumn{2}{c|}{$1.40-2.22$} \\
\hline
\end{tabular}

\section{Kondisi Fisik}

Kondisi fisik meliputi berat badan yang dikategorikan berdasarkan penilaian status gizi dengan menggunakan nilai Z-Score yaitu berdasarkan indeks BB/U (Devi, 2012). Berdasarkan hasil penelitian ini sebaran reponden berdasarkan kondisi fisik

Tabel. 5 Sebaran responden berdasarkan Kondisi Fisik (BB/U)

\begin{tabular}{|l|c|c|c|c|c|c|}
\hline \multirow{2}{*}{ Kondisi Fisik } & \multicolumn{2}{|c|}{ Laki-Laki } & \multicolumn{2}{c|}{ Perempuan } & \multicolumn{2}{c|}{ Total } \\
\cline { 2 - 7 } & $\mathbf{n}$ & $\mathbf{\%}$ & $\mathbf{n}$ & $\mathbf{\%}$ & $\mathbf{n}$ & \% \\
\hline Gizi Buruk & 0 & 0 & 0 & 0 & 0 & 0 \\
\hline Gizi Kurang & 10 & 40.0 & 23 & 51.1 & 33 & 47.14 \\
\hline Gizi Baik & 14 & 56.0 & 22 & 48.9 & 36 & 51.43 \\
\hline Gizi Lebih & 1 & 4.0 & 0 & 0 & 1 & 1.43 \\
\hline Total & 25 & 100 & 45 & 100 & 70 & 100 \\
\hline Rataan \pm SD & $-0.82 \pm 1.25$ & $-1.31 \pm 1.05$ & $-1.14 \pm 1.14$ \\
\hline Min-max & $-2.78-2.00$ & \multicolumn{2}{|l}{$-2.85-1.24$} & $-2.85-2.00$ \\
\hline
\end{tabular}

\section{Hubungan Keseimbangan asupan gizi dengan Kondisi Fisik Anak}

Berdasarkan hasil analisis korelasi Pearson menunjukkan bahwa keseimbangan asupan energi, karbohidrat, vitamin A, vitamin $\mathrm{C}$, fosfor dan besi berhubungan positif nyata $(\mathrm{p}<0.05)$ dengan kondisi fisik, sedangkan kalsium berhubungan positif sangat nyata $(\mathrm{p}<0.01)$ dengan kondisi fisik. Zat gizi lain seperti protein dan lemak tidak menunjukkan hubungan yang nyata dengan kondisi fisik (Tabel 6). Hal ini menunjukkan bahwa semakin baik asupan zat gizi maka kondisi fisik anak juga akan semakin baik. Hal ini sesuai dengan penelitian Arimurti (2010) bahwa terdapat hubungan yang dapat dilihat pada Tabel 5, pada jenis kelamin laki-laki sebanyak 56.0 persen berada pada kategori gizi baik sedangkan pada jenis kelamin perempuan sebanyak 51.1 persen berada pada kategori gizi kurang. 
Hubungan keseimbangan asupan gizi dan aktivitas fisik Dengan kondisi fisik anak sd di kecamatan kotanopan

mengatakan bahwa salah satu masalah gizi pada anak adalah kekurangan zat-zat tertentu, termasuk kalsium. Ketika memasuki usia enam tahun, anak mulai ingin menunjukkan kemampuannya menentukan pilihan atas makanan dan melihat banyaknya pilihan makanan di luar rumah. Anak mulai tidak mudah lagi diatur. Susu sebagai sumber protein hewani dan kalsium juga mulai jarang dikonsumsi, karena asupan kalsium merupakan salah satu zat gizi yang sangat memegang peranan penting dalam menentukan status gizi anak $(\mathrm{BB} / \mathrm{U})$.

Tabel 6. Korelasi Keseimbangan Asupan Gizi dengan Kondisi Fisik Anak

\begin{tabular}{|l|c|c|}
\hline \multirow{2}{*}{$\begin{array}{c}\text { Variabel } \\
\text { Keseimbangan } \\
\text { Asupan Gizi }\end{array}$} & \multicolumn{2}{c|}{ Kondisi Fisik } \\
\cline { 2 - 3 } & $\mathbf{r}$ & Sig (P) \\
\hline Energi & 0.235 & $0.050^{*}$ \\
\hline Karbohidrat & 0.273 & $0.022^{*}$ \\
\hline Lemak & 0.104 & 0.392 \\
\hline Protein & 0.200 & 0.096 \\
\hline Vitamin A & 0.242 & $0.044^{*}$ \\
\hline Vitamin C & 0.254 & $0.034^{*}$ \\
\hline Kalsium & 0.367 & $0.002^{*}$ \\
\hline Fosfor & 0.282 & $0.018^{*}$ \\
\hline Besi & 0.255 & $0.033^{*}$ \\
\hline Kesi
\end{tabular}

Keterangan : $*$ Signifikan pada level 0.05 $* *$ = Signifikan pada level 0.01

\section{Hubungan Aktivitas Fisik dengan Kondisi Fisik Anak}

Berdasarkan hasil analisis korelasi Pearson menunjukkan bahwa terdapat hubungan negatif yang sangat nyata antara aktivitas fisik dengan kondisi fisik dengan nilai $\mathrm{r}=-0.406 ; \mathrm{p}=0.000$. Hal ini menunjukkan bahwa peningkatan aktivitas fisik akan diikuti penurunan kondisi fisik. Aktivitas fisik itu sangat penting untuk memelihara kondisi tubuh yang baik. Karena dengan melakukan aktivitas berarti membakar kalori yang bersumber dari makanan yang telah dikonsumsi. Hal ini sesuai dengan pendapat Khumaidi (2004), yang mengatakan bahwa gaya hidup yang kurang menggunakan aktivitas fisik akan berpengaruh terhadap kondisi tubuh seseorang. Aktivitas fisik tersebut diperlukan untuk membakar energi dari dalam tubuh. Keseimbangan asupan gizi harus diimbangi dengan aktivitas fisik yang dilakukan oleh anak. Karena apabila pemasukan gizi yang menghasilkan energi berlebihan dan tidak diimbangi dengan akivitas fisik akan memudahkan seseorang memiliki berat badan berlebih.

\section{Hubungan Keseimbangan Asupan Gizi dan Aktivitas Fisik dengan Kondisi Fisik Anak}

Berdasarkan hasil analisis regresi linier berganda menunjukkan bahwa terdapat hubungan keseimbangan asupan gizi dan aktivitas fisik dengan kondisi fisik dengan nilai $\mathrm{f}_{\text {hitung }}=2.521>\mathrm{f}_{\text {tabel }}=2.04$ atau $\mathrm{p}$-value $=0.013<\alpha=0.05$. Hal ini berarti keseimbangan asupan gizi dan aktivitas fisik secara simultan berhubungan signifikan dengan kondisi fisik anak. Hal ini sesuai dengan pendapat Khumaidi (2004) yang mengatakan bahwa keseimbangan asupan gizi harus diimbangi dengan aktivitas fisik yang dilakukan oleh anak. Karena apabila pemasukan gizi berlebihan dan tidak diimbangi dengan aktivitas fisik akan memudahkan seseorang memiliki berat badan berlebih.

\section{SIMPULAN}

Berdasarkan hasil penelitian ini maka dapat disimpulkan sebagai berikut:

1. Hubungan keseimbangan asupan gizi dengan kondisi fisik anak dengan uji statistik korelasi Pearson menunjukkan bahwa keseimbangan asupan gizi (energi, karbohidrat, vitamin A, vitamin C, fosfor dan besi) berhubungan positif nyata $(\mathrm{p}<0.05)$ dengan kondisi fisik, sedangkan keseimbangan asupan gizi (kalsium) berhubungan positif sangat nyata $(\mathrm{p}<0.01)$ dengan kondisi fisik. Zat gizi lain seperti protein dan lemak tidak menunjukkan 
Hubungan keseimbangan asupan gizi dan aktivitas fisik Dengan kondisi fisik anak sd di kecamatan kotanopan

hubungan yang nyata dengan kondisi fisik. Hal ini menunjukkan bahwa semakin baik asupan zat gizi maka kondisi fisik anak juga akan semakin baik.

2. Hubungan aktivitas fisik dan kondisi fisik anak dengan uji statistik korelasi Pearson menunjukkan bahwa aktivitas fisik berhubungan negatif sangat nyata $(\mathrm{r}=-$ $0.406 ; \mathrm{p}=0.000)$ dengan kondisi fisik. Hal ini menunjukkan bahwa peningkatan aktivitas fisik akan diikuti penurunan kondisi fisik.

3. Hubungan keseimbangan asupan gizi dan aktivitas fisik dengan kondisi fisik anak dengan uji statistik regresi linier berganda menunjukkan bahwa terdapat hubungan keseimbangan asupan gizi dan aktivitas fisik dengan kondisi fisik dengan nilai $\mathrm{f}_{\text {hitung }}=2.521>\mathrm{f}_{\text {tabel }}=2.04$ atau $\mathrm{p}$-value $=$ $0.013<\alpha=0.05$. Hal ini berarti keseimbangan asupan gizi dan aktivitas fisik secara simultan berhubungan signifikan dengan kondisi fisik anak.

\section{SARAN}

Berdasarkan hasil penelitian ini maka dapat disarankan sebagai berikut:

1. Kepada siswa agar lebih memperhatikan asupan gizinya dengan membiasakan sarapan pagi.

2. Kepada pihak sekolah agar memberikan pendidikan gizi kepada siswa agar dapat memilih makanan yang sehat dan bergizi dan seimbang.

3. Diharapkan pihak sekolah bekerja sama dengan orangtua agar selalu memantau keadaan gizi siswa, agar prestasi belajar di sekolah dapat berjalan maksimal

\section{DAFTAR PUSTAKA}

Arimurti, Triasih.2010. Hubungan Antara Asupan Energi, Karbohidrat, dan Protein dari Makanan Jajanan dengan Status Gizi Anak Sekolah Dasar Usia 9-12 Tahun. Tesis. Fakultas Kedokteran.Universitas Negeri Sebelas Maret.
Arikunto S. 2010. Prosedur Penelitian Suatu pendekatan praktik. Jakarta. PT Rineka Cipta.

Almatsier S. 2001. Prinsip Dasar Ilmu Gizi. Jakarta: Gramedia Pustaka Utama.

Devi N. 2012. Gizi Anak Sekolah. Kompas. Jakarta.

FAO/WHO/UNU. 2001. Human Energy Requirements. FAO/WHO/UNU. Rome.

Handari R. T. Siti dan Siti Humaeroh. 2005. Perbedaan Status Gizi Siswa Sekolah Dasar di Sekolah Berdasarkan Status Sosial Ekonomi di Jakarta Selatan Tahun 2004. Jurnal Kedokteran dan Kesehatan : Universitas Muhammadiyah Jakarta.

Hayati, Ishlah. 2010. Analisis Pertumbuhan Anak Sekolah Dasar dengan Antropometri di Desa Lau Bekeri Kecamtan Kutalimbari Kabupaten Deli serdang. Skripsi. Universitas Sumatera Utara.

Hidayati, dkk, 2006. Obesitas pada Anak. Diakses 26 September 2013. www.pediatric.com

Khomsan A. 2010. Pangan dan Gizi untuk

Kesehatan. Kompas. Rajawali Sport. Jakarta.

Khumaidi. 2004. Gizi Masyarakat. Jakarta: BPK Gunung Mulia.

Moehji S. 2003. Ilmu Gizi 2. Jakara. Papas Sinar Sinanti

Notoatmodjo S. 2003. Ilmu Kesehatan Masyarakat (prinsip-prinsip dasar). Jakarta. Rineka Cipta.

Utari, Putu Sri. 2009. Hubungan Tingkat Pengetahuan Anak Tentang Kesehatan Gigi dan Mulut dengan Perilaku Menggosok Gigi pada Siswa Kelas IV dan V di SD N 1 Pagi Cilandak Timur Jakarta Selatan. Skripsi. Universitas Pembangunan Nasional "Veteran" Jakarta.

[WNPG] Widyakarya Pangan dan Gizi VIII. 2004. LIPI. Jakarta: LIPI. 